\title{
Tip 2 Diyabetli Bireylerin Beslenme Durumlarının Saptanması ve Diyabete Yönelik Davranışlarının Belirlenmesi
}

\author{
Gülşah KANER ${ }^{1} \oplus \llbracket$, Barış Önder PAMUK $^{2} \bullet$, Gülseren PAMUK ${ }^{3} \bullet$, Dilek ONGAN ${ }^{1} \oplus$, \\ Ezgi BELLİKCİ KOYU' ${ }^{\circledR}$, Gamze ÇALIK ${ }^{1} \oplus$, Serap ÖKSÜZ ${ }^{3}$ ๑) \\ 'İzmir Kâtip Çelebi Üniversitesi, Sağlık Bilimleri Fakültesi, Beslenme ve Diyetetik Bölümü, İzmir, Türkiye \\ ${ }^{2}$ İzmir Kâtip Çelebi Üniversitesi, Tıp Fakültesi, İç Hastalıkları Anabilim Dalı, İzmir, Türkiye \\ ${ }^{3}$ İzmir Kâtip Çelebi Üniversitesi, Tıp Fakültesi, Aile Hekimliği Anabilim Dalı, İzmir, Türkiye
}

Bu makaleye yapılacak atıf: Kaner G ve ark. Tip 2 Diyabetli Bireylerin Beslenme Durumlarının Saptanması ve Diyabete Yönelik Davranışlarının Belirlenmesi. Turk J Diab Obes 2021;2: 146-157.

\begin{abstract}
ÖZ
Amaç: $\mathrm{Bu}$ araştırmanın amacı, İzmir ilinde bir üniversite hastanesinin Endokrin Polikliniği'ne başvuran tip 2 diyabetli bireylerin beslenme durumlarının saptanması ve diyabete yönelik davranışlarının belirlenmesidir.

Gereç ve Yöntemler: Araştırmaya, tip 2 diyabetli 135 birey [erkek (n:40), kadın (n:95)] dâhil edilmiştir. Anket formu kullanılarak bireylerin beslenme durumu ve diyabete yönelik davranışları değerlendirilmiştir. Veriler sayı, yüzde, ortalama, standart sapma, ortanca değerleriyle özetlenmiş, nitel verilerin karşılaştırılmasında ki-kare testi uygulanmıştır. Normal dağılan değişkenler için bağımsız örneklemlerde t testi, normal dağılmayan değişkenler için Mann Whitney U testi uygulanmıştır.

Bulgular: Bireylerin ortalama 10,2 $\pm 7,8$ yıldır diyabetli olduğu ve \%53,3’ünün hipoglisemi yaşadığı belirlenmiştir. Bireylerin yarıya yakını $(\% 48,1)$ ana öğünlerini düzenli tüketmektedir. Öğün atlayan bireyler en çok öğle öğününü (\%75,7) atlamakta olup, en temel öğün atlama sebebi açlık hissetmemek olarak bildirilmiştir (\%44,3). Bireylerin posa (E: 21,0 (7,8-47,8) g/gün, K: 18,3 (2,6-75,6) g/gün), folat (E: 248,7 (79,4-738,9) mcg/gün, K: 229,8 (37,8-894,2) mcg/gün), kalsiyum (E: 706,9 (261,7-1990,5) mg/gün, K: 584,6 (76,4-1524,1) mg/ gün) alımları gereksinimlerinin altında olup, sodyum (E: 2887,9 (999,2-7332,2) mg/gün, K: 2421,1 (637,7-7736,6) mg/gün) alımları her iki cinsiyette de yüksek bulunmuştur. Kadınların büyük çoğunluğu $(\% 81,1)$ şişmandır ( $\mathrm{p}=0,003)$. Bel çevresine göre kadınların neredeyse tamamı $(\% 91,3)$ abdominal obezite açısından yüksek risk altındadır ( $\mathrm{p}=0,002)$. Bel/kalça ve bel/boy oranlarına göre hem kadın ve hem erkeklerin çoğunluğu yüksek risk altındadır. Bireylerin \%54,8’i düzenli olarak egzersiz yapmamaktadır.

Sonuç: İzmir ilindeki bir üniversite hastanesinde yapılmış olan bu çalışma sonucunda, diyabetli bireylerin tıbbi beslenme tedavisine ilişkin yanlış uygulamalarının olduğu düşünülmektedir. Diyabete bağlı gelişecek mikro ve makrovasküler komplikasyonların önlenmesi ve vücut ağırlığının denetimi için diyabetlilere sürekli beslenme eğitiminin sağlanması ve izleminin yapılması gerekmektedir.
\end{abstract}

Anahtar Sözcükler: Antropometri, Beslenme durumu, Beslenme alışkanlıkları, Diyabet

\section{Determination of Nutritional Status of Individuals with Type 2 Diabetes and Their Behaviors towards Diabetes}

\begin{abstract}
Aim: The aim of this study is to determine the nutritional status of individuals with type 2 diabetes and their behaviors towards diabetes who applied to the endocrine polyclinic of a university hospital in İzmir.

Material and Methods: A total of 135 individuals with type 2 diabetes [men (n:40), women (n:95)] were included in the study. Nutritional status and behaviors towards diabetes of the individuals were evaluated using the questionnaire. The data were summarized as number, percentage, mean, standard deviation, and median values, and the chi-square test was used to compare qualitative data. Independent Samples t test was used for normally distributed variables, and Mann Whitney U test was used for non-normally distributed variables.
\end{abstract}

ORCID: Gülşah Kaner / 0000-0001-5882-6049, Barış Önder Pamuk / 0000-0003-4784-6380, Gülseren Pamuk / 0000-0001-5556-9630, Dilek Ongan / 0000-0001-8948-9057, Ezgi Bellikci Koyu / 0000-0001-5279-2394, Gamze Çalık / 0000-0002-9160-7750, Serap Öksüz / 0000-0002-6754-2109 
Results: It was determined that individuals had diabetes for a mean age of $10.2 \pm 7.8$ years and 53.3\% of them experienced hypoglycemia. Nearly half (48.1\%) of individuals consume their main meals regularly. Individuals who skipped meals were most likely to skip lunch (75.7\%) and the most basic reason for skipping meals was reported as not feeling hunger (44.3\%). Individuals' fiber (M: 21.0 (7.8-47.8) g/day, W: 18.3 (2.6-75.6) g/day), folate (M: 248.7 (79.4-738.9) mcg/day, W: 229.8 (37.8-894.2) mcg/day), and calcium (M: 706.9 (261.71990.5) $\mathrm{mg} /$ day, W: 584,6 (76.4-1524.1) $\mathrm{mg}$ /day) intake are below their requirements, and sodium intake (M: 2887.9 (999.2-7332.2) mg/day, W: 2421.1 (637.7-7736.6) mg/day) was high in both genders. The majority of women (81.1\%) are obese ( $\mathrm{p}=0.003)$. Almost all women $(91.3 \%)$ are at high risk in terms of abdominal obesity ( $\mathrm{p}=0.002)$. According to waist/hip and waist/height ratios, the majority of both men and women are abdominal obese. $54.8 \%$ of individuals do not exercise regularly.

Conclusion: As a result of this study carried out in a university hospital in İzmir, it is thought that individuals have wrong practices regarding medical nutrition therapy. In order to prevent micro and macrovascular complications resulting from diabetes and to control body weight, it is necessary to provide continuous nutrition education and follow-up the individuals with diabetes.

Keywords: Anthropometry, Nutritional status, Nutritional habits, Diabetes

\section{GİRIŞ}

Uluslararası Diyabet Federasyonu (IDF) 2019 yilında yayınladığı 9. Diyabet Atlası'nda dünyada 463 milyon yetişkinin (20-64 yaş) diyabetli olduğunu bildirmiştir. 2045 yll tahminleri ise bu sayının 700 milyona ulaşacağı yönündedir (1). Ülkemizde de diyabet prevalansının artmakta olduğu bilinmektedir. Ülkemizde 1997-1998 yıllarında yürütülen Türkiye Diyabet Epidemiyoloji (TURDEP-I) çalışması sonuçlarına göre 20 yaş üzerindeki yetişkinlerde diyabet sıklığ $1 \% 7,2$ olarak belirlenmiştir (2). TURDEP I çalışmasının devamı niteliğinde olan ve 2010 yılında gerçekleştirilen TURDEP II çalışmasında ise, diyabet prevalansının önemli ölçüde artarak \%13,7’ye ulaştığı bildirilmiştir (3). IDF’in 2079 yaş arası bireyleri dâhil ederek yaptığı tahminlere göre, 2045 yılında Türkiye, dünyadaki diyabetli sayının en yüksek olduğu 9. ülke olacaktır (1).

Dünyada ve ülkemizde görülen diyabet vakalarının \%9095'ini tip 2 diyabet oluşturmaktadır. Önceki dönemlerde "insüline-bağımlı olmayan diyabet" ya da "yetişkin başlangıçlı diyabet" olarak bilinen tip 2 diyabetin temelinde insülin direnci ve buna bağlı gelişen insülin yetersizliği rol oynamaktadır (4). Tip 2 diyabetin gelişimi çoğunlukla obezite, özellikle de abdominal obezite ile paralellik göstermektedir (4). Obezite dışında ileri yaş, aile öyküsü, düşük sosyo-ekonomik düzey, genetik yatkınlık, gen-çevre etkileşimleri, düzensiz beslenme, fiziksel aktivite yetersizliği ve sigara kullanımı da tip 2 diyabet gelişimi ile ilişkili önemli faktörlerdendir (5). Sağlıklı beslenme, düzenli fiziksel aktivite ve normal vücut ağırlığının sürdürülmesi ile tip 2 diyabeti önlemek ya da geciktirmek mümkündür. Diyabet Önleme Programı (DÖP) çalışması yoğun yaşam tarzı değişiklikleri ile diyabet insidansının 3 yilda \%58 oranında azaltılabileceğini göstermiştir (6). Yoğun yaşam tarzı müdahalelerinin yer aldığı diğer çalışmalarda da benzer sonuçlar elde edilmiştir $(7,8)$. Prediyabetli bireylerde diyabetin önlenmesi ya da geciktirilmesi için oluşturulan mevcut hedefler arasında, başlangıç ağırlığının \%7 oranında azaltılması ve haftada en az 150 dakika orta-ağır şiddetli fiziksel aktivite (tempolu yürüyüş gibi) yapılması yer almaktadır (9).

Beslenme alışkanlarının düzenlenmesi, diyabetin önlenmesinde olduğu kadar diyabetin tedavisinde de önem taşımaktadır. Amerikan Diyabet Derneği (ADA) diyabetin tıbbi beslenme tedavisinde genel öneriler ya da tek tip bir beslenme biçimi yerine kişiye özgü beslenme planlarının düzenlenmesini önermektedir (10). Diyabetli bireylerde tıbbi beslenme tedavisinin hedefleri arasında; uygun porsiyonlarda, besin ögesi içeriği ve çeşitliliği yüksek sağlıklı beslenme modellerinin tüketiminin teşvik edilmesi yer almaktadır. Bu şekilde bir beslenme modeli; hedeflenen vücut ağırlığına ve bireyselleştirilmiş metabolik hedeflere ulaşılmasına, ayrıca diyabet komplikasyonlarının önlenmesi ve geciktirilmesine yardımcı olacaktır (10). Bu araştırma, tip 2 diyabetli bireylerin beslenme durumlarının saptanması ve diyabete yönelik davranışlarının belirlenmesi amacıyla yapılmıştır.

\section{GEREC ve YÖNTEMLER}

\section{Araştırmanın Genel Planı}

$\mathrm{Bu}$ araştırma, "Tip 2 diyabetli bireylere verilen sürekli ve aralıklı beslenme eğitiminin bireylerin metabolik kontrolü ve vücut bileşenleri üzerine etkisi” adlı prospektif olarak iki aşamada yürütülen çalışmanın kesitsel verilerini oluşturmaktadır. Araştırma, Ocak 2017-Nisan 2017 tarihleri arasında, İzmir Kâtip Çelebi Üniversitesi Atatürk Eğitim Araştırma Hastanesi Endokrin Polikliniği' ne başvuran, yaşları 18-64 yıl arasında değișen tip 2 diyabetli bireyler ile yürütülmüştür. Araştırmada örnek seçilmemiş, belirtilen tarihler arasında araştırma ölçütlerine uyan ve çalışmaya katılmayı kabul eden tip 2 diyabetli bireyler araştırmaya dahil edilmiştir. Belirtilen tarihler arasında, araştırmaya katılmaya gönüllü 135 tip 2 diyabetli birey [erkek (n:40), kadın (n:95)] ile çalışma tamamlanmıştır. Güç analizi G*Power Version 3.1.9.6 (Kiel Üniversitesi, Almanya) programında yapılmış- 
tır. Ki-kare testi için yapılan öncül güç analizine göre etki büyüklüğü $=0,37$; serbestlik derecesi $=3$; tip 1 hata $=0,05$ ve istatistiksel güç=0,95 olmak üzere çalışmada 126 kişi ile çalışılmasına karar verilmiştir.

Araştırma için gerekli etik kurul izni, İzmir Kâtip Çelebi Üniversitesi Girişimsel Olmayan Klinik Araştırmalar Etik Kurulu'ndan (Tarih: 11.08.2016, Karar No: 234) alınmıştır. Bu araştırma, İzmir Kâtip Çelebi Üniversitesi Bilimsel Araştırma Projeleri Koordinasyon Birimi (BAP) tarafindan 2016-GAP-SABF-0014 proje numarası ile desteklenmiştir.

Bireylere araștırmanın içeriği ve amacı ile ilgili genel bilgi verilmiş, araștırmaya katılmayı kabul eden her katılımcıya bilgilendirilmiş gönüllü olur formu okutulup imzalatılmış ve çalışma verileri yüz-yüze görüşme yöntemi uygulanarak bir anket formuna kayıt edilmiştir. Anket soruları Beslenme ve Diyetetik alanında uzman 4 araştırmacı tarafından oluşturulmuştur. Anket formu 7 bölümden oluşmuştur. Birinci bölüm, katılımcıların sosyo-demografik özelliklerini saptamaya yöneliktir. İkinci bölümde, genel sağlık durumu ve diyabet tanısına ilişkin bilgiler sorgulanmıştır. Üçüncü bölümde, katılımcıların diyabete yönelik beslenme eğitimi alma durumu ve buna ilişkin değerlendirme soruları yer almıștır. Dördüncü bölümdeki sorular, bireylerin fiziksel aktivite yapma durumlarını belirlemeye yöneliktir. Beşinci bölüm, katılımcıların beslenme alışkanlıklarına ilişkin bilgilerin yer aldığı bölümdür. Altıncı bölümde, beslenme durumunun değerlendirilmesi için, bireylerden geriye dönük 24 saatlik besin tüketim kaydı alınmıştır. Yedinci bölüm ise, bireylerin antropometrik ölçümlerini değerlendirmeye yöneliktir.

\section{Araştırma Verilerinin Toplanması ve Değerlendirilmesi}

\section{Antropometrik Ölçümler}

Bireylerin vücut ağırlıkları TANİTA MC780 MA marka biyoelektrik impedans analiz cihazı ile ölçülmüştür. Ölçüm sırasında ayaklar çıplak ve kuru olarak cihazdaki elektrotlara denk gelecek şekilde yerleştirilmiştir. Boy uzunlukları ise stadiometre ile ölçülmüştür. Bireylerin boy uzunluğu ölçümleri alınırken, ayaklarının birleşik olmasına ve frankfort düzlemde (göz ve kulak kepçesi üstü aynı hizada ve baş ile boyun arasındaki açı 90 derece) olmalarına dikkat edilmiştir. Ayrıca biyoelektrik impedans analizinden elde edilmiş olan vücut yağ kütlesi $(\mathrm{kg})$, kas kütlesi $(\mathrm{kg})$, yağsız vücut kütlesi (kg) ve toplam vücut suyu (kg) değerleri de anket formuna kayıt edilmiştir.

Bireylerin vücut ağırlıkları ve boy uzunlukları kullanılarak beden kütle indeksi (BKİ) değerleri [Vücut ağırlığı $(\mathrm{kg}) /$ (boy uzunluğu $(\mathrm{m}))^{2}$ ] hesaplanmıştır. Dünya Sağlık Örgütü (WHO) sinıflamasina göre BKİ’si 18,50-24,99 kg/m² olanlar normal vücut ağırlı̆̆ında, $25,00-29,99 \mathrm{~kg} / \mathrm{m}^{2}$ olanlar fazla kilolu ve $\geq 30,00 \mathrm{~kg} / \mathrm{m}^{2}$ olanlar obez olarak gruplandırılmıştır.

Bel çevresinin ölçümü için bireyin en alt kaburga kemiği ile kristailiyak arasındaki orta nokta bulunmuş ve bu noktanın çevresi esnemeyen mezura ile ölçülmüştür. Bel çevresinin kadınlarda $\geq 88 \mathrm{~cm}$, erkeklerde ise $\geq 102 \mathrm{~cm}$ olması sağlık açısından yüksek risk olarak değerlendirilmiştir. Bel/kalça oranının kadınlarda $\geq 0,85$, erkeklerde ise $\geq 0,90$ olmasi; bel boy oranının ise $\geq 0,6$ olması abdominal şişmanlık olarak değerlendirilmiştir.

\section{Bireylerin Beslenme Durumunun Saptanması}

Araştırmaya katılan bireylerin beslenme durumunu saptamak amacıyla, geriye dönük 24 saatlik besin tüketim kaydı alınmıştır. Bireylerin tükettikleri yemeklerin porsiyon içerikleri "Kurumlar için Standart Yemek Tarifeleri" kitabından yararlanılarak hesaplanmıştır (11). Kayıtlarda ölçü olarak belirtilmiş yiyeceklerin miktarları "Yemek ve Besin Fotoğraf Kataloğu: Ölçü ve Miktarlar" kitabından yararlanılarak hesaplanmıştır (12). Kaydedilen besinlerin miktarları saptandıktan sonra, Beslenme Bilgi Sistemleri Paket Programı (BEBİS 8.0) kullanılarak günlük enerji, makro ve mikro besin ögeleri hesaplanmıştır (13).

\section{Verilerin Değerlendirilmesi}

Veriler, IBM SPSS 25.0 paket programı (SPSS Inc. Chicago, IL, USA) kullanılarak analiz edilmiştir (14). Kategorik veriler, sayı ve yüzde olarak ifade edilmiş olup; sayısal veriler ise ortalama, standart sapma, ortanca, minimum-maksimum değerleri ile belirtilmiștir. Sürekli değişkenler için normallik varsayımı Kolmogorov Smirnov testi ile kontrol edilmiş, normal dağılan değişkenler için bağımsız örneklemlerde $t$ testi, normal dağılmayan değişkenler için Mann Whitney U testi uygulanmıştır. Nominal değişkenler arasında yapılan ilişki testlerinde çapraz tablolar kullanılarak ki-kare istatistiği ile yorumlamalar gerçekleştirilmiştir. Sonuçlar \%95'lik güven aralığında, anlamlılık $\mathrm{p}<0,05$ düzeyinde değerlendirilmiştir.

\section{BULGULAR}

Diyabetli bireylerin sosyo-demografik özellikleri Tablo 1'de verilmiştir. Araştırmaya alınan bireylerin \%70,4'ü kadın,

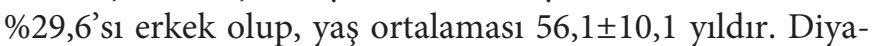
betlilerin \%74,1'i evli, çoğu ilkokul ve lise mezunudur (s1rasıyla; \%45,9 ve \%20,7). Bireylerin çoğunlukla ev hanımı $(\% 51,9)$ ve emekli $(\% 23,0)$ olduğu belirlenmiş; $\% 68,9$ 'unun ailesinde diyabet öyküsü olduğu saptanmıştır.

Tablo 2'de bireylerin diyabete ilişkin özellikleri gösterilmiştir. Bireylerin ortalama $10,2 \pm 7,8$ yldır diyabetli olduğu ve üç diyabetliden birinin $(\% 36,8)$ oral antidiyabetik (OAD) 
tedavisi aldığ 1 tespit edilmiştir. Bununla birlikte, bireylerin $\% 7,5$ 'i sadece tıbbi beslenme tedavisi (TBT), \%7,5'i TBT+insülin tedavisi ve \%11,3'ü TBT+OAD tedavisi almaktadır. Diyabetli bireylerin \%53,3'ü hipoglisemi yaşadığını belirtmiştir. Hipoglisemi yaşayan bireylerin üçte biri $(\% 34,5)$ haftada 1 kez veya daha sık hipoglisemi yaşadığını ifade etmiştir. Hipoglisemi durumunda en sık yapılan ilk üç uygulama çay şekeri $(\% 36,5)$, meyve+süt grubu besin $(\% 17,3)$ veya ekmek+peynir $(\% 12,9)$ tüketmektir. Hastaların \%76,3'ünde diyabete eşlik eden hastalıkların mevcut olduğu saptanmıştır. En sık görülen ilk üç komorbidite hipertansiyon $(\% 50,0)$, kalp-damar hastalığ $(\% 13,3)$ ve tiroid fonksiyon bozukluklarıdır $(\% 10,4)$. En sık görülen ilk üç komplikasyon hipertansiyon $(\% 53,3)$, nöropati $(\% 34,8)$ ve retinopati $(\% 28,1)$ 'dir.

Tip 2 diyabetli bireylerin beslenme eğitimi alma durumları değerlendirildiğinde; \%60,7'sinin daha önce beslenme eğitimi aldığg ve bireylerin çoğunluğuna $(\% 69,5)$ bu eğitimin diyetisyen tarafından verildiği belirlenmiştir. Beslenme eğitimi alan bireylerin $\% 60,9$ 'u bu eğitimi 1 yll veya daha

Tablo 1: Diyabetli bireylerin sosyo-demografik özellikleri $(\mathrm{n}=135)$

\begin{tabular}{lc}
\hline Sosyo-demografik özellikler & n (\%) \\
\hline Cinsiyet & \\
\hline Erkek & $40(29,6)$ \\
\hline Kadın & $95(70,4)$ \\
\hline Medeni durum & $100(74,1)$ \\
\hline Evli & $35(25,9)$ \\
\hline Bekâr & \\
\hline Eğitim durumu & $14(10,4)$ \\
\hline Okuryazar değil & $6(4,5)$ \\
\hline Okuryazar & $62(45,9)$ \\
\hline İlkokul & $14(10,4)$ \\
\hline Ortaokul & $28(20,7)$ \\
\hline Lise & $10(7,4)$ \\
\hline Üniversite & $1(0,7)$ \\
\hline Yüksek lisans-doktora & $70(51,9)$ \\
\hline Meslek & $31(23,0)$ \\
\hline Ev hanımı & $19(14,0)$ \\
\hline Emekli & $7(5,2)$ \\
\hline Serbest meslek & $7(5,2)$ \\
\hline İşçi & $1(0,7)$ \\
\hline Memur & $93(68,9)$ \\
\hline Çalışmıor & $42(31,1)$ \\
\hline Ailede diyabet hastası birey bulunma durumu & \\
\hline Var & \\
\hline Yok & \\
\hline
\end{tabular}

Tablo 2: Diyabetli bireylerin diyabete ilişkin bulguları

\begin{tabular}{|c|c|}
\hline Diyabete ilișkin bulgular & n (\%) \\
\hline Alınan tedavi & $(n=133)$ \\
\hline Oral antidiyabetik & $49(36,8)$ \\
\hline İnsülin & $14(10,5)$ \\
\hline Tibbi beslenme tedavisi (TBT) & $10(7,5)$ \\
\hline Oral antidiyabetik+insülin & $35(26,4)$ \\
\hline Oral antidiyabetik+TBT & $15(11,3)$ \\
\hline İnsülin+TBT & $10(7,5)$ \\
\hline Hipoglisemi yaşama durumu & $(n=135)$ \\
\hline Evet & $72(53,3)$ \\
\hline Hayır & $63(46,7)$ \\
\hline Hipoglisemi sıklığı & $(n=58)$ \\
\hline Her gün & $12(20,6)$ \\
\hline Haftada 1 kez veya daha sık & $20(34,5)$ \\
\hline Ayda 1 kez & $8(13,8)$ \\
\hline Ayda 2 kez ve daha sık & $9(15,6)$ \\
\hline Ayda 1 kereden daha seyrek & $6(10,3)$ \\
\hline Seyrek & $3(5,2)$ \\
\hline Hipoglisemi durumunda uygulama ${ }^{*}$ & $(\mathrm{n}=93)$ \\
\hline Çay şekeri almak & $34(36,5)$ \\
\hline Ekmek ve peynir tüketmek & $12(12,9)$ \\
\hline Sadece ekmek yemek & $6(6,5)$ \\
\hline Meyve ve süt grubu besin tüketmek & $16(17,3)$ \\
\hline Diğer** & $25(26,8)$ \\
\hline Diğer hastalık bulunma durumu & $(n=135)$ \\
\hline Yok & $32(23,7)$ \\
\hline Var & $103(76,3)$ \\
\hline \multicolumn{2}{|l|}{ Diğger hastalıklar* } \\
\hline Hipertansiyon & $72(50,0)$ \\
\hline Kalp-damar hastalı̆̆ & $19(13,3)$ \\
\hline Tiroid fonksiyon bozukluğu & $15(10,4)$ \\
\hline Hiperlipidemi & $13(9,0)$ \\
\hline Gastrointestinal sistem hastalı̆̆ & $8(5,5)$ \\
\hline Böbrek hastalıkları & $7(4,9)$ \\
\hline Astım & $6(4,2)$ \\
\hline Diğer (anemi, alerji, inflamatuvar hastalık) & $4(2,7)$ \\
\hline \multicolumn{2}{|l|}{ Diyabete ilişkin var olan komplikasyonlar* } \\
\hline Retinopati & $38(28,1)$ \\
\hline Nefropati & $18(13,3)$ \\
\hline Nöropati & $47(34,8)$ \\
\hline Hipertansiyon & $72(53,3)$ \\
\hline İskemik kalp hastalığ & $29(21,5)$ \\
\hline Ayak yarası & $14(10,4)$ \\
\hline Ampütasyon & $2(1,5)$ \\
\hline
\end{tabular}

*Birden fazla seçenek işaretlenmiştir. ${ }^{*}$ Su, bal, tatll, çikolata, bisküvi, meyve, meyve suyu, akide şekeri, gazlı içecek, sert kabuklu meyve 
uzun süre önce aldığını ifade etmiştir. Tip 2 diyabetli bireylere eğitim vermesi gereken sağlık personeli ve tercih ettikleri eğitim yöntemi de sorulmuştur. Buna göre bireyler eğitimlerin diyetisyen $(\% 54,8)$ ve doktor $(\% 23,2)$ tarafindan verilmesi gerektiğini belirtmiştir. Eğitim alırken bireylerin yarıya yakını $(\% 47,5)$ görsel kaynakların kullanılmasını tercih etmektedir. Bireylerin yarısı $(\% 50,0)$ daha önce aldıkları beslenme önerilerine uymakta olduğunu belirtmiştir (Tablo 3).

Diyabetli bireylerin beslenme alışkanlıkları Tablo 4'te gösterilmiștir. Diyabetli bireylerin yarıya yakını $(\% 48,2)$ ana öğünlerini düzenli tüketmektedir. Öğün atlayan bireyler en çok öğle ögününü $(\% 75,7)$ atlamakta olup, en temel ögün atlama sebebi açlık hissetmemek olarak bildirilmiştir $(\% 44,3)$. Diyabetli bireylerin $\% 67,9^{\prime}$ u ara öğün yaptığını ifade etmiştir. Ara öğünde en sık tüketilen besinler; meyve $(\% 25,9)$, meyve+süt grubu besinler $(\% 17,5)$, ceviz/badem/ findıktır $(\% 12,6)$.

Diyabetli bireylerin 24 saatlik geriye dönük bireysel besin tüketim kayıtlarına göre belirlenen enerji ve besin ögesi alımları Tablo 5'de görülmektedir. Diyetle alınan günlük toplam enerji erkekler için; 1539 (644-2251) kkal/gün, kadınlar için 1203 (423-3088) kkal/gün'dür $(\mathrm{p}<0,05)$. Erkeklerin $(950.9(308,6-1714,7) \mathrm{mL})$ kadınlara $(712,8$ (222,12035,9 mL) göre diyetle aldıkları su miktarının daha fazla olduğu belirlenmiştir $(\mathrm{p}<0,05)$. Toplam protein, yağ, kolesterol, $B_{2}$ vitamini, $B_{12}$ vitamini, sodyum, potasyum, kalsiyum ve fosfor alımlarının erkeklerde (sırasıyla; 66.5 (31,4-106,1) g, 69,3 $\pm 24,7 \mathrm{~g}, 344,5(61,0-647,9) \mathrm{mg}, 1,2(0,6-2,4) \mathrm{mg}, 3,8$ (0,8-17,9) mg, 2887,9 (999,2-7332,2) mg, 2409,0 (1050,5$3676,7) \mathrm{mg}, 706,9$ (261,7-1990,5) mg, (119,6 (559,2-1674,0)

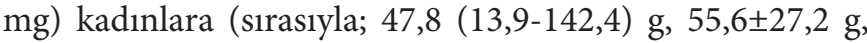
237,9 (10,7-651,1) mg, 0,9 (0,3-2,9) mg, 2,5 (0,0-15,1) mg, $2421,1(637,7-7736,6) \mathrm{mg}, 1941,2(333,8-5660,9) \mathrm{mg}, 584,6$ (76,4-1524,1) mg, 914,9 (214,5-2749,5) mg) göre anlamlı olarak daha yüksek olduğu saptanmıştır $(\mathrm{p}<0,05)$. Enerjinin protein, karbonhidrat ve yağdan gelen oranları erkeklerde sirasiyla; $\% 18,6 \pm 4,8, \% 39,9 \pm 10,0$ ve $\% 41,2 \pm 8,3$, kadınlarda sirasiyla; $\% 16,7 \pm 5,3, \% 42,8 \pm 13,9$ ve $\% 41,2 \pm 12,6$ olarak saptanmıştır. Bireylerin posa (E: $21,0(7,8-47,8) \mathrm{g} /$ gün, K: $18,3(2,6-75,6) \mathrm{g} /$ gün$)$, folat (E: $248,7(79,4-738,9) \mathrm{mcg} / \mathrm{gün}$, K: 229,8 (37,8-894,2) mcg/gün), kalsiyum (E: 706,9 (261,71990,5) mg/gün, K: 584,6 (76,4-1524,1) mg/gün) alımlarının gereksinimlerinin altında olduğu, sodyum (E: 2887,9 (999,2-7332,2) mg/gün, K: 2421,1 (637,7-7736,6) mg/gün) alımlarının ise her iki cinsiyette de yüksek olduğu belirlenmiştir.

Vücut ağırlığı, bel ve kalça çevresi gibi antropometrik ölçümlere ilişkin sonuçlar Tablo 6'da verilmiştir. Erkeklerin ve kadınların ortalama BKİ değerleri sırasıyla; 30,4 $\pm 5,0$
Tablo 3: Diyabetli bireylerin beslenme eğitim alma durumuna ilişkin bulgular

\begin{tabular}{lc}
\hline $\begin{array}{l}\text { Beslenme eğitim alma durumuna ilişkin } \\
\text { bulgular }\end{array}$ & n (\%) \\
\hline Eğitim almış olma durumu & $(\mathbf{n}=\mathbf{1 3 5 )}$ \\
\hline Evet & $82(60,7)$ \\
\hline Hayır & $53(39,3)$ \\
\hline Eğitim veren sağlık personeli* & \\
\hline Doktor & $16(19,5)$ \\
\hline Diyetisyen & $57(69,5)$ \\
\hline Hemşire & $19(23,1)$ \\
\hline Eğitim alma sayısı & $(\mathbf{n}=\mathbf{8 2})$ \\
\hline 1 kez & $38(46,4)$ \\
\hline $2 \mathrm{kez}$ & $17(20,7)$ \\
\hline $3 \mathrm{kez}$ & $5(6,1)$ \\
\hline$\geq 4 \mathrm{kez}$ & $22(26,8)$ \\
\hline
\end{tabular}

Eğitim alma zamanı

1 yll önce $13(15,8)$

$2-5$ yıl önce $20(24,4)$

6-10 y1l önce $11(13,4)$

$\geq 11$ yıl önce $6(7,3)$

Eğitim şekli $\quad(\mathbf{n}=\mathbf{8 1})$

Bireysel $39(48,1)$

Toplu seans $34(42,0)$

Bireysel ve toplu $\quad 8(9,9)$

Eğitim verilme şekli*

Sözel anlatım $20(15,6)$

Sözel anlatım+doküman $55(42,9)$

Doküman verilmedi $6(4,7)$

Görsel kaynak kullanıldı $20(15,6)$

Slayt gösterisi kullanıldı $19(14,8)$

Beslenme ile ilgili önerilerin uygulanma durumu $(\mathbf{n}=\mathbf{8 2})$

Evet $41(50,0)$

Hayır $17(20,7)$

Uygulamış, daha sonra bırakmış $24(29,3)$

Hastalara göre eğitimi vermesi gereken sağlık personeli

\begin{tabular}{lc}
\hline Diyetisyen & $45(54,8)$ \\
\hline Doktor & $19(23,2)$ \\
\hline Hemşire & $3(3,7)$ \\
\hline Diyetisyen+doktor & $8(9,8)$ \\
\hline Diyetisyen+hemşire & $2(2,4)$ \\
\hline Hepsi & $5(6,1)$ \\
\hline
\end{tabular}

Hastalara göre en etkili eğitim yöntemi ${ }^{\star}$

Sadece sözel anlatım $13(15,8)$

Sözel anlatım+doküman $\quad 35(42,7)$

Slayt gösterisi/görsel kaynaklar $39(47,5)$

*Birden fazla seçenek işaretlemiştir. 
$\mathrm{kg} / \mathrm{m}^{2}$ ve $35,1 \pm 6,2 \mathrm{~kg} / \mathrm{m}^{2}$, bel çevresi; $107,4 \pm 13,6 \mathrm{~cm}$ ve $109,6 \pm 14,4 \mathrm{~cm}$, bel/kalça oranı; $0,98 \pm 0,07$ ve $0,92 \pm 0,07$ olarak bulunmuştur. Bireylerin vücut ağırlığı ile ilişkili sağlık risklerinin değerlendirilmesi Tablo 7'de sunulmuş̧tur. Kadınların büyük çoğunluğu $(\% 81,1)$ şişmandır (BKİ $\geq 30,00$ $\left.\mathrm{kg} / \mathrm{m}^{2}\right)(\mathrm{p}=0,003)$. Bel çevresine göre diyabetli kadınların neredeyse tamamı $(\% 91,3)$ sağlık açısından çok yüksek risk altındadır $(\mathrm{p}=0,002)$. Bel/kalça ve bel/boy oranlarına göre hem kadın ve hem erkek bireylerin çoğunluğu abdominal obezite açısından yüksek risk altındadır.

Bireylerin egzersiz yapma durumuna ilişkin veriler Tablo 8 'de sunulmuştur. Diyabetli bireylerin \%54,8'i düzenli olarak egzersiz yapmamaktadır. Bireyler, sağlık sorunları $(\% 37,7)$, alışkanlığının olmaması $(\% 27,8)$ ve zaman yetersizliği $(\% 18,0)$ nedenleriyle egzersiz yapmadığını belirtmiştir.

\section{TARTIŞMA}

Ülkemizde yürütülen TURDEP II çalışmasında tip 2 diyabetin kadınlarda ve eğitim düzeyi düşük bireylerde daha yaygın olduğu ve yaşla birlikte arttığı belirlenmiştir (3). Bu çalışmanın sonuçları da TURDEP-II çalışması ile uyumludur. Medeni durum ile diyabet arasındaki ilişkiyi inceleyen çalışma sonuçları ise farklılık göstermektedir. Erkeklerde bekâr olmanın tip 2 diyabet riskinde azalma ile de, artma ile de ilişkili olduğunu gösteren çalışmalar bulunmaktadır $(3,15)$. Bunun yanı sıra, medeni durum ile diyabet riski arasında ilişki olmadığını rapor eden çalışma da mevcuttur (16). Bu çalışmada katılımcıların büyük çoğunluğunun evli olduğu $(\% 74,1)$ bulunmuş̧ur. Aile öyküsü ile diyabet riski arasında güçlü bir ilişki olduğu bilinmektedir (17-19). Bu çalışmada da bireylerin çoğunluğunun $(\% 68,9)$ ailelerinde diyabet öyküsü olduğu belirlenmiştir.

Amerika Birleşik Devletleri Ulusal Beslenme ve Sağlık Araştırması (NHANES) 2005-2012 yılı sonuçlarına göre, tip 2 diyabetli bireylerin \%29,1'i insülin tedavisi almaktadır (20). Bu çalışmada ise, insülin tedavisi alan bireylerin oranı \%44,4 olarak belirlenmiştir. Diyabet yaşının insülin kullanımının bağımsız bir belirleyicisi olduğu bilinmektedir (20). Bu çalışmadaki yüksek orandaki insülin kullanımının nedenlerinden birisi bireylerin ortalama 10 yıldan uzun süredir diyabet hastası olmaları ile ilişkilendirilebilir. Yapılan bu araştırmada, bireylerin yarıdan fazlası $(\% 53,3)$ hipoglisemi yaşadığını belirtmiş ve bu bireylerin \%34.5’i haftada en az bir kez hipoglisemi yaşadığını ifade etmiştir. İnsülin kullanımı ile hipoglisemi riskinin arttığı düşünüldüğünde, çalışmaya katılan bireylerdeki insülin kullanma oranlarının yüksekliği, hipoglisemi görülme riski ve sıklığındaki yüksekliğin açıklayıcısı olabilir (21). Türkiye Endokrinoloji ve Metabolizma Derneği'nin Diabetes mellitus ve komplikas-
Tablo 4: Diyabetli bireylerin beslenme alışkanlıkları

\begin{tabular}{|c|c|}
\hline Beslenme alışkanlıkları & n (\%) \\
\hline Düzenli ana öğün tüketimi & $(n=135)$ \\
\hline Evet & $65(48,2)$ \\
\hline Hayır & $37(27,4)$ \\
\hline Bazen & $33(24,4)$ \\
\hline Atlanan öğün & $(n=70)$ \\
\hline Kahvaltı & $12(17,1)$ \\
\hline Öğle & $53(75,7)$ \\
\hline Akşam & $3(4,4)$ \\
\hline Kahvaltı+öğle & $1(1,4)$ \\
\hline Kahvalt1+akşam & $1(1,4)$ \\
\hline Öğün atlama sebebi & $(\mathrm{n}=\mathbf{8 8})$ \\
\hline İş yoğunluğundan dolayı vakit bulamamak & $20(22,7)$ \\
\hline Açlık hissetmemek & $39(44,3)$ \\
\hline $\begin{array}{l}\text { Bulunduğu yerde uygun yemeklerin } \\
\text { olmaması }\end{array}$ & $8(9,1)$ \\
\hline Üç ana öğün yapmayı gereksiz görmek & $4(4,5)$ \\
\hline $\begin{array}{l}\text { Öğün atlayarak kan şekerinin daha düzenli } \\
\text { olacağını düşünmek }\end{array}$ & $2(2,3)$ \\
\hline Zayıflamak istemek & $6(6,8)$ \\
\hline Diğer (Uyumak için, canı istemediği için) & $9(10,3)$ \\
\hline Ara öğün yapma durumu & $(n=135)$ \\
\hline Evet & $91(67,9)$ \\
\hline Hayır & $44(32,1)$ \\
\hline Ara öğün yapma sıklığı (kez/günde) & $(n=92)$ \\
\hline 1 & $16(17,4)$ \\
\hline 2 & $43(46,7)$ \\
\hline 3 & $29(31,5)$ \\
\hline$\geq 4$ & $4(4,4)$ \\
\hline Atlanan ara öğün & $(n=74)$ \\
\hline Kuşluk & $31(41,9)$ \\
\hline İkindi & $21(28,4)$ \\
\hline Gece & $16(21,6)$ \\
\hline Kuşluk+ikindi & $3(4,1)$ \\
\hline İkindi+gece & $2(2,7)$ \\
\hline Kuşluk+ikindi+gece & $1(1,3)$ \\
\hline \multicolumn{2}{|l|}{ Ara öğünde tüketilenler* } \\
\hline Meyve+süt/yoğurt/ayran & $42(17,5)$ \\
\hline Meyve+ceviz/badem/findık & $19(7,9)$ \\
\hline Meyve & $62(25,9)$ \\
\hline Ceviz/badem/findık & $30(12,6)$ \\
\hline Ekmek+peynir & $19(7,9)$ \\
\hline Galeta/grisini & $15(6,4)$ \\
\hline Tatlı bisküviler & $14(5,9)$ \\
\hline Tuzlu bisküviler & $17(7,2)$ \\
\hline Domates, salatalık, biber gibi çiğ sebzeler & $21(8,7)$ \\
\hline
\end{tabular}

*Birden fazla seçenek işaretlenmiştir. 
Tablo 5: Diyabetli bireylerin enerji ve besin ögesi alımları

\begin{tabular}{|c|c|c|c|c|}
\hline & Erkek $(n=40)$ & Kadın (n=95) & & \\
\hline Enerji ve besin ögeleri & $\begin{array}{c}\overline{\mathrm{X}} \pm \mathrm{SS} \\
\text { Medyan (min-maks) }\end{array}$ & $\begin{array}{c}\overline{\mathrm{X}} \pm \mathrm{SS} \\
\text { Medyan (min-maks) }\end{array}$ & Test istatistiği & $\mathbf{p}$ \\
\hline Enerji (kkal) & $1539(644-2251)$ & $1203(423-3088)$ & $\mathrm{U}=1376,0$ & $0,012^{*}$ \\
\hline $\mathrm{Su}(\mathrm{mL})$ & $950,9(308,6-1714,7)$ & $712,8(222,1-2035,9)$ & $\mathrm{U}=1219,0$ & $0,001^{*}$ \\
\hline Protein $(\mathrm{g})$ & $66,5(31,4-106,1)$ & $47,8(13,9-142,4)$ & $\mathrm{U}=1250,0$ & $0,002^{\star}$ \\
\hline Protein (\%) & $18,6 \pm 4,8$ & $16,7 \pm 5,3$ & $\mathrm{t}=-1,943$ & 0,054 \\
\hline Karbonhidrat (g) & $140,3(28,1-301,5)$ & $118,9(35,6-408,2)$ & $\mathrm{U}=1676,0$ & 0,280 \\
\hline Karbonhidrat (\%) & $39,9 \pm 10,0$ & $42,8 \pm 13,9$ & $\mathrm{t}=1,211$ & 0,228 \\
\hline Fruktoz (g) & $14,3(0,3-35,6)$ & $9,7(0,1-73,1)$ & $\mathrm{U}=1524,5$ & 0,070 \\
\hline Yağ (g) & $69,3 \pm 24,7$ & $55,6 \pm 27,2$ & $\mathrm{t}=-2,725$ & $0,007^{*}$ \\
\hline Yağ (\%) & $41,2 \pm 8,3$ & $41,2 \pm 12,6$ & $\mathrm{t}=-2,581$ & $0,011^{*}$ \\
\hline Kolesterol (mg) & $344,5(61,0-647,9)$ & $237,9(10,7-651,1)$ & $\mathrm{U}=1256,0$ & $0,002^{*}$ \\
\hline n-6 yağ asidi (g) & $5,4(1,8-23,9)$ & $5,5(1,3-37,5)$ & $\mathrm{U}=1712,0$ & 0,365 \\
\hline $\mathrm{n}-3$ yağ asidi $(\mathrm{g})$ & $0,9(0,4-4,8)$ & $1,0(0,3-6,0)$ & $\mathrm{U}=1825,5$ & 0,720 \\
\hline$n-6 / n-3$ & $5.3(2,8-28,9)$ & $4,9(1,1-63,9)$ & $\mathrm{U}=1593,0$ & 0,139 \\
\hline Posa $(\mathrm{g})$ & $21,0(7,8-47,8)$ & $18,3(2,6-75,6)$ & $\mathrm{U}=1859,0$ & 0,843 \\
\hline A vitamini $(\mu \mathrm{g})$ & $769,3(386,7-5704,4)$ & $701,9(139,4-3518,6)$ & $\mathrm{U}=1534,0$ & 0,078 \\
\hline Karoten $(\mu \mathrm{g})$ & $2,0(0,2-28,0)$ & $1,7(0,1-18,4)$ & $\mathrm{U}=1763,5$ & 0,511 \\
\hline E vitamini (mg) & $7,9(3,4-24,5)$ & $6,4(0,7-48,1)$ & $\mathrm{U}=1583,5$ & 0,127 \\
\hline $\mathrm{B}_{1}$ vitamini $(\mathrm{mg})$ & $0,8(0,4-1,5)$ & $0,7(0,2-2,2)$ & $\mathrm{U}=1587,5$ & 0,132 \\
\hline $\mathrm{B}_{2}$ vitamini $(\mathrm{mg})$ & $1,2(0,6-2,4)$ & $0,9(0,3-2,9)$ & $\mathrm{U}=1248,0$ & $0,002^{*}$ \\
\hline Niasin (mg) & $9,9(2,9-24,7)$ & $8,1(2,7-46,9)$ & $\mathrm{U}=1560,0$ & 0,101 \\
\hline $\mathrm{B}_{6}$ vitamini $(\mathrm{mg})$ & $1,1(0,4-2,1)$ & $1,0(0,2-4,5)$ & $\mathrm{U}=1687,5$ & 0,306 \\
\hline $\mathrm{B}_{12}$ vitamini $(\mathrm{mg})$ & $3,8(0,8-17,9)$ & $2,5(0,0-15,1)$ & $\mathrm{U}=1296,5$ & $0,004^{\star}$ \\
\hline Folat $(\mu \mathrm{g})$ & $248,7(79,4-738,9)$ & $229,8(37,8-894,2)$ & $\mathrm{U}=1699,0$ & 0,333 \\
\hline C vitamini (mg) & $94,6(17,3-393,2)$ & $96,6(3,7-1066,5)$ & $\mathrm{U}=1868,0$ & 0,877 \\
\hline Sodyum (mg) & $2887,9(999,2-7332,2)$ & $2421,1(637,7-7736,6)$ & $\mathrm{U}=1432,0$ & $0,024^{*}$ \\
\hline Potasyum (mg) & $2409,0(1050,5-3676,7)$ & $1941,2(333,8-5660,9)$ & $\mathrm{U}=1429,0$ & $0,023^{*}$ \\
\hline Kalsiyum (mg) & $706,9(261,7-1990,5)$ & $584,6(76,4-1524,1)$ & $\mathrm{U}=1449,0$ & $0,030^{\star}$ \\
\hline Magnezyum (mg) & $238,2(105,5-531,5)$ & $224,8(59,3-745,1)$ & $\mathrm{U}=1713,0$ & 0,368 \\
\hline Fosfor (mg) & $1146,5 \pm 326,3$ & $976,1 \pm 458,6$ & $\mathrm{t}=-2,131$ & $0,035^{\star}$ \\
\hline Demir (mg) & $8,9(4,6-22,2)$ & $8,4(1,9-24,6)$ & $\mathrm{U}=1816,0$ & 0,686 \\
\hline Çinko (mg) & $8,2(4,4-18,8)$ & $7,2(2,2-26,2)$ & $\mathrm{U}=1513,0$ & 0,062 \\
\hline
\end{tabular}

yonlarının tanı, tedavi ve izlem kılavuzu, hipoglisemi durumunda 15-20 g glikoz içeren (tercihen 3-4 glikoz tablet/jel, 4-5 kesme şeker veya 150-200 mL meyve suyu ya da limonata) hızlı etkili karbonhidratların tüketimini önermektedir (22). Çikolata, gofret gibi yağ içerikli ürünlerin ise kullanılmaması gerektiği bildirilmiştir. Hipoglisemik atak sonrası, hastanın öğün planında 30 dakika içinde yemek programı yoksa ek olarak 15-20 g kompleks karbonhidrat alınmas1 önerilmektedir. Bu araştırmada, bireylerin hipoglisemi durumunda uyguladıkları başlıca yöntemler arasında şeker $(\% 36,5)$, meyve-süt grubu besin $(\% 17,3)$ ve peynir-ekmek tüketmek $(\% 12,9)$ yer almaktadır. Bu sonuçlar, hipoglisemi tedavisinde öncelikle kan şekerini hızla yükseltecek besinlerin tüketilmesine ilişkin bilgi ve uygulama eksikliği olduğunu göstermektedir. Hipertansiyonun diyabetle birlikteliği sık görülen bir durumdur $(23,24)$. Bu çalışmaya katılan bireylerin de \%50,0'sinde diyabete hipertansiyonun eşlik ettiği saptanmıştır. Hipertansiyonun, aterosklerotik kardiyovasküler hastalıklar, kalp krizi ve mikrovasküler komplikasyonlar için güçlü bir risk faktörü olduğu ve diyabetik bireylerde mortalite ve morbiditenin başlıca nedeni olduğu düşünüldüğünde hastaların yarısının önemli ölçüde risk altında olduğu görülmektedir (23). Hipertansiyon dışında, diyabet yaşının artışı ve kötü glisemik kontrol de mikro- 
Tablo 6: Diyabetli bireylerin antropometrik ölçümleri

\begin{tabular}{lcc}
\hline \multirow{2}{*}{ Antropometrik özellikler } & Erkek $(\mathbf{n = 4 0 )}$ & Kadın (n=95) \\
\cline { 2 - 3 } & $\overline{\mathbf{X}} \mathbf{\text { SS }}$ & $\overline{\mathbf{X}} \mathbf{\text { SS }}$ \\
\hline Vücut ağırlı̆̆ $(\mathrm{kg})$ & $87,6 \pm 15,7$ & $85,8 \pm 15,9$ \\
\hline Beden kütle indeksi $\left(\mathrm{kg} / \mathrm{m}^{2}\right)$ & $30,4 \pm 5,0$ & $35,1 \pm 6,2$ \\
\hline Vücut yağ oranı $(\%)$ & $27,4 \pm 9,4$ & $41,3 \pm 6,4$ \\
\hline Vücut yağ kütlesi $(\mathrm{kg})$ & $25,4 \pm 13,2$ & $36,4 \pm 11,4$ \\
\hline Vücut kas kütlesi $(\mathrm{kg})$ & $59,7 \pm 7,8$ & $47,9 \pm 6,2$ \\
\hline Bel çevresi $(\mathrm{cm})$ & $107,4 \pm 13,6$ & $109,6 \pm 14,4$ \\
\hline Kalça çevresi $(\mathrm{cm})$ & $108,8 \pm 9,8$ & $118,2 \pm 12,2$ \\
\hline Bel/kalça oranı & $0,98 \pm 0,07$ & $0,92 \pm 0,07$ \\
\hline Bel/boy oranı & $0,63 \pm 0,08$ & $0,70 \pm 0,09$ \\
\hline
\end{tabular}

Tablo 7: Diyabetli bireylerin BKİ sınıflaması ve antropometrik ölçümler ile ilişkili sağlık riskinin değerlendirilmesi

\begin{tabular}{|c|c|c|c|}
\hline \multirow{2}{*}{ Antropometrik ölçümler } & Erkek $(n=40)$ & Kadın (n=95) & \multirow{2}{*}{$p^{a}$} \\
\hline & n (\%) & n (\%) & \\
\hline \multicolumn{3}{|l|}{ BKİ $\left(\mathbf{k g} / \mathbf{m}^{2}\right)$} & \multirow{5}{*}{$0,003^{\star}$} \\
\hline Zayıf $(<18,50)$ & - & - & \\
\hline Normal $(18,50-24,99)$ & $6(15,0)$ & $5(5,3)$ & \\
\hline Fazla kilolu $(25,00-29,99)$ & $13(32,5)$ & $13(13,7)$ & \\
\hline Şişman $(\geq 30,00)$ & $21(52,5)$ & $77(81,1)$ & \\
\hline Bel çevresi $(\mathrm{cm})$ & $(n=39)$ & $(n=92)$ & \multirow{4}{*}{$0,002^{*}$} \\
\hline Sağlık riski düşük $(\mathrm{E}:<94 \mathrm{~cm}, \mathrm{~K}:<80 \mathrm{~cm})$ & $6(15,4)$ & $3(3,3)$ & \\
\hline Sağlık riski yüksek (E: $\geq 94-<102 \mathrm{~cm}, \mathrm{~K}: \geq 80-<88)$ & $7(17,9)$ & $5(5,4)$ & \\
\hline Sağlık riski çok yüksek (E: $\geq 102 \mathrm{~cm}, \mathrm{~K}: \geq 88)$ & $26(66,7)$ & $84(91,3)$ & \\
\hline Bel/kalça oranı & $(\mathrm{n}=38)$ & $(n=92)$ & \multirow{3}{*}{0,788} \\
\hline Sağlık riski düşük $(\mathrm{E}:<0,90, \mathrm{~K}:<0,85)$ & $4(10,5)$ & $13(14,1)$ & \\
\hline Sağlık riski yüksek $(\mathrm{E}: \geq 0,90, \mathrm{~K}: \geq 0,85)$ & $34(89,5)$ & $79(85,9)$ & \\
\hline Bel/boy oranı & $(n=39)$ & $(n=90)$ & \multirow{4}{*}{$0,010^{*}$} \\
\hline$<0,4$ & - & - & \\
\hline$\geq 0,4-<0,5$ & $3(7,7)$ & $3(3,3)$ & \\
\hline$\geq 0,5-<0,6$ & $10(25,6)$ & $7(7,8)$ & \\
\hline$\geq 0,6$ & $26(66,7)$ & $80(88,9)$ & \\
\hline
\end{tabular}

Tablo 8: Diyabetli bireylerin egzersiz yapma durumu

\begin{tabular}{lc}
\hline Egzersiz yapma durumu & $\mathbf{n}(\mathbf{\%})$ \\
\hline Düzenli egzersiz yapma durumu & $(\mathbf{n}=\mathbf{1 3 5 )}$ \\
\hline Evet & $61(45,2)$ \\
\hline Hayır & $74(54,8)$ \\
\hline Egzersiz yapmama nedeni & $(\mathbf{n}=\mathbf{6 1})$ \\
\hline Zaman yetersizliği & $11(18,0)$ \\
\hline Sağlık sorunları & $23(37,7)$ \\
\hline Yaşanan yerde egzersiz olanaklarının olmaması & $8(13,1)$ \\
\hline Maddi imkân yetersizliği & $1(1,7)$ \\
\hline Alışkanlığın olmaması & $17(27,8)$ \\
\hline Tembellik & $1(1,7)$ \\
\hline
\end{tabular}

vasküler komplikasyon riskini artırmaktadır $(25,26)$. Nitekim, bu çalışmaya katılan bireylerde diyabetin mikrovasküler komplikasyonlarından retinopati $(\% 28,1)$ ve nöropati $(\% 34,8)$ görülme oranları yüksektir. Bu durumun bireylerin uzun yıllardır diyabetli olmaları ve çalışmaya katılan bireylerdeki yüksek hipertansiyon prevalansı nedeniyle şaşırtıcı olmadığı söylenebilir.

Tip 2 diyabetlilerin tanıyı izleyen ilk 6 ay içinde 3-6 izlemi kapsayan tıbbi beslenme tedavisi eğitimi alması önerilmektedir. Ayrıca, yaşam tarzı değişikliklerinin desteklenmesi ve tedavinin değerlendirilmesi için de eğitimin yıllık en az bir görüşme ile devam etmesi gerektiği bildirilmektedir (27). Bu çalışmaya katılan bireylerin daha önce beslenme eğitimi 
alıp almadığı sorgulandığında, \%39,3'ünün daha önce hiç eğitim almadığı saptanmıştır. Eğitim aldığını belirten bireylerin de \%46,4'ünün sadece bir kez eğitim aldığı belirlenmiştir. Bir yıldan kısa süre önce eğitim aldığını bildiren bireyler $(\mathrm{n}=32)$ tüm eğitim alanların \%39, l'ini oluşturmaktadır. Bu sonuçlar, rehberlerde önerilen eğitim sürelerinin ve sıklığının altında bir hizmet sunulduğunu göstermektedir. Sağlık profesyonellerinin hasta yükünü karşılayacak kadar yeterli sayıda olmaması, diyabetli bireylerin izlendiği klinik ve polikliniklerde ekip içinde diyetisyenin görevlendirilmemesi, hastaların eğitim seanslarına katılma konusundaki isteksizlikleri gibi nedenler rehberlerde belirtilen sıklıkta beslenme eğitimi verilmesini engelleyen faktörler olabilir. Bununla birlikte, bu bulgular diyabette tıbbi beslenme tedavisi eğitimine ilişkin önemli bir eksikliği ortaya koymaktadır. Beslenme eğitiminin sıklı̆̆ının kısıtlılığı göz önüne alındığında diyabetli bireylere verilecek eğitimin sıklığı konusunda standardizasyon getirilmesinin verimli olabileceği düşünülmektedir. Beslenme eğitiminde verilen önerilerin uygulanma durumları sorgulandığında bireylerin yarısı önerileri uyguladığını, \%20,7'si uygulamadığını, \%29,3'ü ise önce uyguladığını sonrasında ise bıraktığını bildirmiştir. Bireylere verilen eğitim sıklığının yetersizliği diyetin zamanla bırakılması veya uygulanmamasının temel nedeni olabilir.

Diyabetli bireylerde ögün planlaması bireyin yaşam şekli ve beslenme alışkanlıkları dikkate alınarak günde 2-3 ana ve 2-4 ara öğün olacak şekilde yapılır (28). Ancak, tıbbi beslenme tedavisi ile birlikte oral antidiyabetik ya da karışım insülin kullananlarda karbonhidrat alımının öğün ve ara ögünlere dağıtılması ve günden güne değişmeden benzer miktarlarda olması önerilmektedir (22). Bu çalışmaya katılan bireylerin yarısından fazlasının ana öğünleri düzenli tüketmediği ve ögün atladığı belirlenmiştir. Ögün düzeni ile ilgili çalışmalar genellikle kahvaltı üzerine odaklanmıştır. Kahvaltı öğününün atlanmasının tip 2 diyabet riskini artırdığı bildirilmektedir (29). Ayrıca, kahvaltı öğününü atlayan tip 2 diyabetlilerde glisemik kontrolün daha kötü olduğu ve Hbalc değerlerinin daha yüksek olduğu da saptanmıştır (30). Bu çalışmada, kahvaltı ögününü atlayanların oranın yüksek olmadığı belirlenmiştir. Buna karşın, ögün atlayan bireylerin çoğunun öğle ögününü atladığı gözlenmiştir. Bu çalışmaya katılan bireylerin ara öğün tüketimleri değerlendirildiğinde katılımcıların çoğunluğunun $(\% 67,9)$ ara öğün tükettiği belirlenmiştir. Ara öğünlerde tercih ettikleri besinler sorgulandığında büyük çoğunluğunun sağlıklı besinleri içeren tercihler yaptığı saptanmıştır. Bu bulgular doğrultusunda, ara ögün tüketimi ve tüketilen besinlerin türü açısından hastaların bilinçli olduğu söylenebilir.

Tip 2 diyabetli bireylerin beslenme planlarında makro besin ögelerinin dağılımı konusunda net sınırlar olmamakla bir- likte, Diabetes mellitus ve komplikasyonlarının tanı, tedavi ve izlem kılavuzunda enerji gereksiniminin \%45-60'ının karbonhidratlardan, \%10-20'sinin proteinlerden ve \%20 -35’inin yağlardan karşılanması önerilmektedir (22). Doymuş yağın toplam enerjinin \%7'sinden az olacak şekilde s1nırlandırılması, diyetle kolesterol alımının 200 mg/gün'ün altında olması ve posa alımının $14 \mathrm{~g} / 1000$ kkal olacak şekilde alımı önerilmektedir (22). Bu çalışmaya katılan bireylerin besin tüketim kayıtlarından elde edilen sonuçlar doğrultusunda, yağdan gelen enerjinin ve günlük diyetle alınan ortalama kolesterol miktarının yüksek olduğu görülmüştür. Ortalama enerji alımlarına göre değerlendirilen posa alımlarının ise yetersiz olduğu saptanmıştır. Bununla birlikte yapılan bu araştırmada, diyetle alınan protein, yağ ve kolesterol alımı açısından cinsiyetler arasında fark olduğu, erkek diyabetlilerin kadınlara göre diyetle aldıkları protein, yağ ve kolesterol düzeylerinin daha fazla olduğu belirlenmiştir. Besin tüketim kayıtları baz alınarak yürütülen diğer çalışmalarda da, benzer şekilde diyabetli bireylerin enerji ve besin öğesi alımlarının beslenme rehberlerindeki önerilere uygun olmadığı belirlenmiştir (31-33). Çalışmaların birçoğunda gözlenen ortak nokta yağdan ve doymuş yağdan gelen enerjinin yüksek oluşudur. İtalya'da yürütülen bir çalı̧̧mada, tip 2 diyabetli bireylerde yağdan ve doymuş yağdan gelen enerjinin yüzdelerinin sırasıyla kadınlarda $\% 37,0$ ve $\% 12,0$; erkeklerde $\% 36,4$ ve $\% 11,5$ olduğu belirlenmiştir. Günlük 200 mg'ın altında alınması önerilen kolesterol değerlerinin de kadın ve erkeklerde sirasiyla $304 \mathrm{mg}$ ve 344 mg olduğu saptanmıştır. Aynı çalışmada bireylerin alması gereken posa miktarlarının da yetersiz olduğu bildirilmiştir (31). Fransa'da yürütülen karşılaştırma çalışmalarında $\mathrm{da}$, hem diyabetli bireylerde ve hem de diyabeti olmayan kontrol gruplarında toplam yağ ve doymuş yağ alımlarının önerilerin üzerinde, posa alımlarının ise önerilerin altında olduğu bulunmuştur $(32,33)$. Diyabetli bireylerde gelişebilecek mikro ve makrovasküler komplikasyon riski düşünüldüğünde bu beslenme alışkanlıklarının değiştirilmesine yönelik daha çok çaba harcanması gerektiği söylenebilir. Diyabetli bireylerin mikro besin ögeleri gereksinimlerinin genel popülasyondan farklı olmadığı bildirilmiştir (22). Antioksidan vitaminler olan $\mathrm{A}, \mathrm{C}$ ve $\mathrm{E}$ vitaminlerinin oksidatif stresi ve inflamatuvar yanıtı azaltarak diyabette olumlu etkileri olduğu bilinmektedir. Bu vitaminlerin düzeylerinin diyabetli bireylerde düşük olduğu, bu nedenle yeterli miktarlarda tüketilmesi gerektiği bildirilmiştir (34). Türkiye Beslenme Rehberi'ne göre $\mathrm{A}, \mathrm{C}$ ve $\mathrm{E}$ vitaminleri için günlük alınması gereken miktarlar sırasıyla; kadınlarda $650 \mathrm{mcg} /$ gün, $95 \mathrm{mg} /$ gün ve $11 \mathrm{mg} /$ gün'dür (35). Erkeklerde ise bu değerler sirasiyla, $750 \mathrm{mcg} / \mathrm{gün}, 100 \mathrm{mg} /$ gün ve $13 \mathrm{mg} / \mathrm{gün}$ olarak belirlenmiştir (35). Bu çalışmada, bireylerin diyetle aldığı günlük ortalama $\mathrm{A}, \mathrm{C}$ ve $\mathrm{E}$ vitamini miktarları değer- 
lendirildiğinde; A ve $\mathrm{C}$ vitaminlerinin yeterli alındığ 1 , buna karşın E vitamini alımının yeterli olmadığı gözlenmiştir. Diyabet komplikasyonları açısından önemli olan tiamin ve $\mathrm{B}_{6}$ vitaminlerinin de diyabetli bireylerde düzeylerinin daha düşük olduğu belirlenmiştir (36). Türkiye Beslenme Rehberi'nde tiamin ve $B_{6}$ vitamini için günlük önerilen alım miktarları kadınlar için sırasıyla 1,1 mg ve 1,3 mg'dır (35). Erkeklerde ise bu vitaminlerin önerilen miktarları 1,2 mg ve 1,3 mg olarak belirlenmiştir (35). Bu çalışmada, kadınlarda ve erkeklerde ortalama tiamin ve $B_{6}$ vitamini alımlarının yetersiz olduğu saptanmıştır. B grubu vitaminlerinden folat ve $B_{12}$ vitamininin, metabolik sendromlu bireylerde homosistein düzeylerini düşürdüğü, endotel fonksiyon ve insülin direnci üzerine olumlu etkilerinin olduğu gösterilmiştir (36). Oral antidiyabetik olarak uzun dönem metformin kullanan hastalarda, bu vitaminlerin eksikliği görülebilmektedir. $\mathrm{Bu}$ nedenle, diyabetli bireylerin tıbbi beslenme tedavisinde bu besin ögelerinden yeterli düzeyde alımın sağlanmasına dikkat edilmelidir (34). Türkiye Beslenme Rehberi'nde $B_{12}$ ve folik asit için günlük önerilen alım miktarları sırasıyla $4 \mathrm{mg}$ ve 330 mcg olarak belirtilmiştir (35). Buna karşın bu çalışmada, $B_{12}$ vitamini alımının kadınlarda, folik asit alımının ise her iki cinsiyette de yetersiz olduğu saptanmıştır. Minerallerden potasyumun yeterli düzeyde alımı (4,7 g/gün) kan basıncının regülasyonu ve kardiyovasküler riskin azaltılması için önemlidir (37). Bu çalışmada gözlenen yüksek hipertansiyon prevalansı da düşünüldügüünde potasyumun yeterli miktarlarda alınması önemlidir. Buna karşın bu çalışmaya katılan bireylerin potasyum alım ortalamalarının her iki cinsiyet için de yetersiz olduğu görülmektedir. Magnezyum ve kalsiyum da diyabet ile sıkça ilişkilendirilmektedir. Magnezyum; glikoz ve lipit metabolizmasındaki enzimler için önemli bir kofaktördür (38). Diyetle magnezyum alımı ile tip 2 diyabet riski arasındaki ilişkinin değerlendirildiği bir meta-analizde, diyetle alınan magnezyumdaki her 100 mg'lık artışın tip 2 diyabet riskini \%8-13 oranında azalttığ belirlenmiştir (39). Kalsiyum da adipozitenin azaltılmas1, vazodilatasyon ve insülin salınımının düzenlenmesi ile ilişkilendirilmektedir (40). Bu nedenle, diyabetli hastaların diyetlerinde bu minerallerin yeterli düzeyde alınmasına dikkat edilmelidir. Ancak bu çalışmaya katılan bireylerde kalsiyum ve magnezyumun ortalama alımlarının hem kadınlarda hem de erkeklerde Türkiye Beslenme Rehberi'nde belirtilen değerlerin altında kaldığı gözlenmiştir.

Diyabetin en önemli risk faktörünün obezite olduğu bilinmektedir (41). Bu çalışmada da hem kadınların hem erkeklerin BKİ ortalamaları $30,00 \mathrm{~kg} / \mathrm{m}^{2}$ nin üzerindedir. Abdominal obezitenin göstergesi olan bel çevresi ölçümleri ve bel/boy oranları da önerilen değerlerin üzerindedir. Bu durum, bireylerin diyabetli olarak geçirdikleri yıllar süresince tedavi hedeflerine (ideal vücut ağırlıklarına) ulaşamadığını göstermektedir.
Fiziksel aktivite yetersizliği diyabetin önemli risk faktörlerindendir (41). Diabetes mellitus ve komplikasyonlarının tanı, tedavi ve izlem kılavuzunda mevcut komplikasyonlara adapte edilerek planlanmış düzenli fiziksel aktivitenin tüm diyabetli hastalara önerilmesi gerektiği belirtilmektedir (22). Fiziksel aktivite ve egzersizin, diyabetli bireylerde kan glikoz regülasyonu, kan basıncı kontrolü, dislipidemi ve vücut ağırlığı kaybı üzerine olumlu etkileri vardır. Buna karşın bu çalışmada, bireylerin sadece $\% 45,2$ 'sinin düzenli egzersiz yaptığ 1 belirlenmiştir. Bireylerin $\% 54,8$ 'inde ise hedeflenen egzersiz önerilerine ulaşılmadığı saptanmıştır. Macaristan'da yapılan bir çalışmada da, diyabetli bireylerin \%33,8'inin fiziksel aktivite önerilerine uymadığı saptanmıştır (42). Hindistan'da yapılan başka bir çalışmada da fiziksel aktivite önerilerine uyumun düşük olduğu gösterilmiştir (43). Fiziksel ve mental sağlık durumunun elverişli olmaması, fiziksel aktiviteye ilgi duyulmaması, zaman yetersizliği, yorgunluk hissi, stresli yaşam şartları gibi çeşitli etmenler egzersiz yapmama nedenleri arasında gösterilmektedir. Bunun yanı sıra hava durumu, kültürel bariyerler, çevresel şartların yetersiz oluşu, egzersizin nasıl yapılacağına ilişkin bilgi eksikliği ve sosyal destek eksikliği gibi faktörlerin de etkili olduğu bildirilmiştir (44). Bu çalışmaya katılan bireylerde de sağlık sorunları, alışkanlığın olmaması ve zaman yetersizliği egzersiz yapmama nedenleri arasında başta gelen faktörlerdendir.

$\mathrm{Bu}$ araştırma, İzmir ilindeki bir üniversite hastanesinde planlanmış ve yürütülmüştür. Dolayısıyla elde edilen sonuçlar bu bölgeyi yansıtmaktadır. Bu durum araştırmanın sınırlılığını oluşturmaktadır. Araştırma sonucunda, diyabetli bireylerin tıbbi beslenme tedavisine ilişkin yanlış uygulamalarının olduğu düşünülmektedir. Diyabete bağlı gelişecek mikro ve makrovasküler komplikasyonların önlenmesi ve vücut ağırlı̆̆ının denetimi için diyabetli bireylere sürekli beslenme eğitiminin sağlanması ve izleminin yapılması gerekmektedir.

Teşekkür

Çalışmanın yapılmasını destekleyen İzmir Kâtip Çelebi Üniversitesi Bilimsel Araştırma Projeleri Koordinasyon Birimi’ne teşekkür ederiz.

Yazarların Makaleye Katkı Beyanı

Fikir/kavram: Gülşah Kaner, Tasarım: Gülşah Kaner, Barıș Önder Pamuk, Gülseren Pamuk, Dilek Ongan, Ezgi Bellikci Koyu Denetleme/danışmanlık: Gülşah Kaner, Barış Önder Pamuk, Veri toplama ve/veya işleme: Gamze Çalık, Serap Öksüz, Analiz ve/veya yorum: Dilek Ongan, Kaynak taraması: Gülșah Kaner, Ezgi Bellikci Koyu, Makalenin Yazılması: Gülşah Kaner, Ezgi Bellikci Koyu, Eleștirel inceleme: Barıș Önder Pamuk, Gülseren Pamuk, Dilek Ongan, Ezgi Bellikci Koyu, Gamze Çalık, Serap Öksüz 


\section{Çıkar Çatıșması}

Yazarlar çıkar çatışması bildirmemiştir.

Finansal Destek

Bu araştırma için finansal destek, İzmir Kâtip Çelebi Üniversitesi Bilimsel Araştırma Projeleri Koordinasyon Birimi tarafından verilmiştir.

\section{Etik Kurul Onayı}

Araştırma için gerekli etik kurul izni, İzmir Kâtip Çelebi Üniversitesi Girişimsel Olmayan Klinik Araştırmalar Etik Kurulu'ndan (Tarih: 11.08.2016, Karar No: 234) alınmıștır.

\section{KAYNAKLAR}

1. International Diabetes Federation. IDF Diabetes Atlas, 9th edition. Brussels, Belgium: International Diabetes Federation, 2019.

2. Satman I, Yilmaz T, Sengül A, Salman S, Salman F, Uygur S, Bastar I, Tütüncü Y, Sargin M, Dinççag N, Karsidag K, Kalaça S, Ozcan C, King H. Population-based study of diabetes and risk characteristics in Turkey: Results of the turkish diabetes epidemiology study (TURDEP). Diabetes Care. 2002;25(9):1551-1556.

3. Satman I, Omer B, Tutuncu Y, Kalaca S, Gedik S, Dinccag N, Karsidag K, Genc S, Telci A, Canbaz B, Turker F, Yilmaz T, Cakir B, Tuomilehto J; TURDEP-II Study Group. Twelve-year trends in the prevalence and risk factors of diabetes and prediabetes in Turkish adults. Eur J Epidemiol. 2013;28(2):169-180.

4. American Diabetes Association. Standards of medical care in diabetes-2019. Diabetes Care. 2019;42(1):13-28.

5. Zheng Y, Ley SH, Hu FB. Global aetiology and epidemiology of type 2 diabetes mellitus and its complications. Nat Rev Endocrinol. 2018;14(2):88-98.

6. Knowler WC, Barrett-Connor E, Fowler SE, Hamman RF, Lachin JM, Walker EA, Nathan DM; Diabetes Prevention Program Research Group. Reduction in the incidence of type 2 diabetes with lifestyle intervention or metformin. N Engl J Med. 2002;346(6):393-403.

7. Li G, Zhang P, Wang J, An Y, Gong Q, Gregg EW, Yang W, Zhang B, Shuai Y, Hong J, Engelgau MM, Li H, Roglic G, Hu $\mathrm{Y}$, Bennett PH. Cardiovascular mortality, all-cause mortality, and diabetes incidence after lifestyle intervention for people with impaired glucose tolerance in the Da Qing Diabetes Prevention Study: A 23-year follow-up study. Lancet Diabetes Endocrinol. 2014;2(6):474-480.

8. Lindström J, Ilanne-Parikka P, Peltonen M, Aunola S, Eriksson JG, Hemiö K, Hämäläinen $H$, Härkönen $P$, KeinänenKiukaanniemi S, Laakso M, Louheranta A, Mannelin M, Paturi M, Sundvall J, Valle TT, Uusitupa M, Tuomilehto J; Finnish Diabetes Prevention Study Group. Sustained reduction in the incidence of type 2 diabetes by lifestyle intervention: Follow-up of the Finnish Diabetes Prevention Study. Lancet. 2006;368(9548):1673-1679.
9. American Diabetes Association. 3. Prevention or delay of type 2 diabetes: Standards of Medical Care in Diabetes-2020. Diabetes Care. 2020;43(1):S32-S36.

10. American Diabetes Association. Standards of medical care in diabetes-2020. Diabetes Care. 2020;43(1):S33-S50.

11. Kutluay Merdol T. Standart Yemek Tarifeleri: Toplu Beslenme Yapılan Kurumlar İçin. 4. Baskı, Ankara, Hatipoğlu Yayınevi, 2004.

12. Rakıcıoğlu N, Tek Acar N, Ayaz A, Pekcan G. Yemek ve Besin Fotoğraf Kataloğu Ölçü ve Miktarlar. 4. Baskı, Ankara, Ata Ofset Yayınevi, 2014.

13. Beslenme Bilgi Sistemi (BEBİS) Versiyon 8. Ebispro for Windows, Stuttgart, Germany; Turkish version BeBiS, Versiyon 8; Data bases 2010. Bundeslebenmittelschlüssel (BLS), 11.3 and other sources. Available from: http://www. bebis.com.tr

14. IBM Corp. Released 2017. IBM SPSS Statistics for Windows, Version 25.0. Armonk, NY: IBM Corp.

15. Cornelis MC, Chiuve SE, Glymour MM, Chang SC, Tchetgen Tchetgen EJ, Liang L, Koenen KC, Rimm EB, Kawachi I, Kubzansky LD. Bachelors, divorcees, and widowers: Does marriage protect men from type 2 diabetes? PloS one. 2014;9(9):e106720.

16. Rahmanian K, Shojaei M, Sotoodeh Jahromi A. Relation of type 2 diabetes mellitus with gender, education, and marital status in an Iranian urban population. Rep Biochem Mol Biol. 2013;1(2):64-68.

17. Yılmaz A, Kılınç F, Usman M, Sucakli M, Tanrıverdi H, Aslanhan H, Bucaktepe G, Kars V. The prevalence of diabetes mellitus, dysglycaemia and factors that affect them in public employees of Kahramanmaras. TJFMPC. 2015;9(3):99-103.

18. Valdez R, Yoon PW, Liu T, Khoury MJ. Family history and prevalence of diabetes in the U.S. population. The 6-year results from the National Health and Nutrition Examination Survey (1999-2004). Diabetes Care. 2007;30(10):2517-2522.

19. InterAct Consortium, Scott RA, Langenberg C, Sharp SJ, Franks PW, Rolandsson O, Drogan D, van der Schouw YT, Ekelund U, Kerrison ND, Ardanaz E, Arriola L, Balkau B, Barricarte A, Barroso I, Bendinelli B, Beulens JW, Boeing H, de LauzonGuillain B, Deloukas P, Fagherazzi G, Gonzalez C, Griffin SJ, Groop LC, Halkjaer J, Huerta JM, Kaaks R, Khaw KT, Krogh V, Nilsson PM, Norat T, Overvad K, Panico S, RodriguezSuarez L, Romaguera D, Romieu I, Sacerdote C, Sánchez MJ, Spijkerman AM, Teucher B, Tjonneland A, Tumino R, van der A DL, Wark PA, McCarthy MI, Riboli E, Wareham NJ. The link between family history and risk of type 2 diabetes is not explained by anthropometric, lifestyle or genetic risk factors: The EPIC-InterAct study. Diabetologia. 2013;56(1):60-69.

20. Selvin E, Parrinello CM, Daya N, Bergenstal RM. Trends in insulin use and diabetes control in the U.S.: 1988-1994 and 1999-2012. Diabetes Care. 2016;39(3):e33-e35.

21. Edridge CL, Dunkley AJ, Bodicoat DH, Rose TC, Gray LJ, Davies MJ, Khunti K. Prevalence and incidence of hypoglycaemia in 532,542 people with type 2 diabetes on oral therapies and insulin: A systematic review and meta-analysis of population based studies. PloS one. 2015;10(6):e0126427. 
22. Türkiye Endokrinoloji ve Metabolizma Derneği. Diabetes mellitus ve komplikasyonlarının tanı, tedavi ve izlem kılavuzu-2019. Ankara: Türkiye Endokrinoloji ve Metabolizma Derneği.

23. de Boer IH, Bangalore S, Benetos A, Davis AM, Michos ED, Muntner P, Rossing P, Zoungas S, Bakris G. Diabetes and hypertension: A position statement by the American Diabetes Association. Diabetes Care. 2017;40(9):1273-1284.

24. Lastra G, Syed S, Kurukulasuriya LR, Manrique C, Sowers JR. Type 2 diabetes mellitus and hypertension: An update. Endocrinol Metab Clin North Am. 2014;43(1):103-122.

25. Fawwad A, Mustafa N, Zafar AB, Khalid M. Incidence of microvascular complications of type 2 diabetes: A 12 year longitudinal study from Karachi-Pakistan. Pak J Med Sci. 2018;34(5):1058-1063.

26. Maghbooli Z, Pasalar P, Keshtkar A, Farshad F, Bagher L. Predictive factors of diabetic complications: A possible link between family history of diabetes and diabetic retinopathy. J Diabetes Metab Disord. 2014;13:55.

27. Franz MJ, MacLeod J, Evert A, Brown C, Gradwell E, Handu D, Reppert A, Robinson M. Academy of nutrition and dietetics nutrition practice guideline for type 1 and type 2 diabetes in adults: Systematic review of evidence for medical nutrition therapy effectiveness and recommendations for integration into the nutrition care process. J Acad Nutr Diet. 2017;117(10):1659-1679.

28. Türkiye Diyabet Vakfı. Diyabet tanı ve tedavi rehberi. 2018. İstanbul: Türkiye Diyabet Vakfi.

29. Bi H, Gan Y, Yang C, Chen Y, Tong X, Lu Z. Breakfast skipping and the risk of type 2 diabetes: A meta-analysis of observational studies. Public Health Nutr. 2015;18(16):30133019.

30. Reutrakul S, Hood MM, Crowley SJ, Morgan MK, Teodori $\mathrm{M}$, Knutson KL.The relationship between breakfast skipping, chronotype, and glycemic control in type 2 diabetes. Chronobiol Int. 2014;31(1):64-71.

31. Vitale M, Masulli M, Cocozza S, Anichini R, Babini AC, Boemi M, Bonora E, Buzzetti R, Carpinteri R, Caselli C, Ceccarelli E, Cignarelli M, Citro G, Clemente G, Consoli A, Corsi L, De Gregorio A, Di Bartolo P, Di Cianni G, Fontana L, Garofolo M, Giorda CB, Giordano C, Grioni S, Iovine C, Longhitano S, Mancastroppa G, Mazzucchelli C, Montani V, Mori M, Perriello G, Rinaldi ME, Ruffo MC, Salvi L, Sartore G, Scaranna C, Tonutti L, Zamboni C, Zogheri A, Krogh V, Cappellini F, Signorini S, Riccardi G, Vaccaro O; TOSCA.IT Study Group. Sex differences in food choices, adherence to dietary recommendations and plasma lipid profile in type 2 diabetes-The TOSCA. IT study. Nutr Metab Cardiovasc Dis. 2016;26(10):879-885.

32. Gauthier-Chelle K, Mennen L, Arnault N, Rigalleau V, Herchberg S, Gin H. Comparison of the diet of self-declared diabetics with non-diabetic patients in the SU.VI.MAX study: Did the diabetics modify their nutritional behavior? Diabetes Metab. 2004;30(6):535-542.
33. Castetbon K, Bonaldi C, Deschamps V, Vernay M, Malon A, Salanave B, Druet C. Diet in 45- to 74-year-old individuals with diagnosed diabetes: Comparison to counterparts without diabetes in a nationally representative survey (Etude Nationale Nutrition Santé 2006-2007). J Acad Nutr Diet. 2014;114(6):918925.

34. Valdes-Ramos R, Guadarrama-Lopez AL, Martinez-Carrillo $\mathrm{BE}$, Benítez-Arciniega AD. Vitamins and type 2 diabetes mellitus. Endocr Metab Immune Disord Drug Targets. 2015;15(1):54-63.

35. Sağlık Bakanlığı. Türkiye Beslenme Rehberi (TÜBER). 2015. Ankara: Sağlık Bakanlığı.

36. Setola E, Monti LD, Galluccio E, Palloshi A, Fragasso G, Paroni R, Magni F, Sandoli EP, Lucotti P, Costa S, Fermo I, GalliKienle M, Origgi A, Margonato A, Piatti P. Insulin resistance and endothelial function are improved after folate and vitamin B12 therapy in patients with metabolic syndrome: Relationship between homocysteine levels and hyperinsulinemia. Eur J Endocrinol. 2004;151(4):483-489.

37. Kovesdy CP, Appel LJ, Grams ME, Gutekunst L, McCullough PA, Palmer BF, Pitt B, Sica DA, Townsend RR. Potassium homeostasis in health and disease: A scientific workshop cosponsored by the National Kidney Foundation and the American Society of Hypertension. J Am Soc Hypertens. 2017;11(12):783-800.

38. Barbagallo M, Dominguez LJ. Magnesium metabolism in type 2 diabetes mellitus, metabolic syndrome and insulin resistance. Arch Biochem Biophys. 2007;458(1):40-47.

39. Fang X, Han H, Li M, Liang C, Fan Z, Aaseth J, He J, Montgomery S, Cao Y. Dose-response relationship between dietary magnesium intake and risk of type 2 diabetes mellitus: A systematic review and meta-regression analysis of prospective cohort studies. Nutrients. 2016;8(11):739.

40. Pittas AG, Lau J, Hu FB, Dawson-Hughes B. The role of vitamin $\mathrm{D}$ and calcium in type 2 diabetes. A systematic review and meta-analysis. J Clin Endocrinol Metab. 2007;92(6):20172029.

41. World Health Organization. Global report on diabetes, 2016.

42. Hankó B, Kázmér M, Kumli P, Hrágyel Z, Samu A, Vincze Z, Zelkó R. Self-reported medication and lifestyle adherence in Hungarian patients with type 2 diabetes. Pharm World Sci. 2007;29(2):58-66.

43. Arulmozhi S, Mahalakshmy T. Self care and medication adherence among type 2 diabetics in Puducherry, Southern India: A hospital based study. J Clin Diagn Res. 2014;8(4):Uc01Uc03.

44. Laitinen JH, Alahuhta MA, Korkiakangas EE. Barriers to regular exercise among adults at high risk or diagnosed with type 2 diabetes: A systematic review. Health Promot Int. 2009;24(4):416-427. 